\title{
Investigation of Chemical Composition and Antibacterial Activity of Ink from Sea Hare Dolabella auricularia
}

\author{
Janeth Cuevas TAYONE \\ Institute of Agriculture and Life Sciences, Davao Oriental State University, Guang-guang, Dahican, \\ City of Mati, Davao Oriental, Philippines
}

(Corresponding author; e-mail: njtayone2005@yahoo.com)

Received: 23 September 2016, Revised: 20 September 2018, Accepted: 30 October 2018

\begin{abstract}
This study was conducted to determine the chemical composition of ink from sea hare (Dolabella auricularia) of Pujada Bay, City of Mati, Davao Oriental. The proximate and mineral composition were determined by using the standard official methods of the Association of Official Analytical Chemists (AOAC). The presence of secondary metabolites was investigated by using different qualitative tests, namely Froth test (saponins), Libermann-Buchard (sterols), Bate-Smith and Metacalf (flavonoids), Dragendorff and Maeyer (alkaloids), Keller-kiliani (glycoside), ferric chloride (tannins) and Bortnträger (anthraquinones). Its antibacterial activity against Escherichia coli and Staphylococcus aureus was determined by using agar well diffusion method. The results for proximate analyses showed that ink contained $90.4 \%$ moisture, $2.044 \%$ ash, $5.324 \%$ crude fat and $0.75 \%$ protein. The mineral analyses were $0.25 \%$ phosphorous, $578 \mu \mathrm{g} / \mathrm{g}$ potassium, $0.662 \%$ sodium, $310.8 \mu \mathrm{g} / \mathrm{g}$ calcium, $664 \mu \mathrm{g} / \mathrm{g}$ magnesium, $2.146 \mu \mathrm{g} / \mathrm{g}$ iron and $1.898 \mu \mathrm{g} / \mathrm{g}$ zinc. Secondary metabolites screening revealed that ink contained saponins, steroids and flavonoids. Further, the ink extract showed weak antibacterial factor. This is the first study conducted on the ink of sea hare in Davao region and its preliminary results showed that it is a good source of primary and secondary metabolites. These findings can be added to the potential medicinal value of sea hare and a basis for further chemical studies that will hopefully lead to the discovery of compounds with pharmacological importance.
\end{abstract}

Keywords: Dolabella auricularia, primary and secondary metabolites, antibacterial, Pujada Bay, sea hare

\section{Introduction}

The biological and chemical biodiversity of the marine environment is immeasurable and is, therefore, an extraordinary resource for the discovery of various drugs. Marine organisms competing for survival in the challenging ocean environment produce chemicals that provide ecological advantage. Research technologies and medical advances in structure elucidation and biological assay showed that these chemicals can be developed as pharmaceuticals and used for biomedical and industrial applications [1].

Dolabella auricularia or sea hare is a marine organism that belongs to Phylum Mollusca. Its scientific name, Anaspidea, is derived from the Greek word which means without shield. It has two long ear-like projections that makes it look like "sea bunnies" [2]. Dolabella auricularia is normally found in sheltered bays or lagoons, in grass beds or on sandy-muddy substrate. It feeds on a variety of brown, green and red macro algae [3]. When threatened, sea hares squirt a copious protective secretion from its gland in the mantle cavity (Figure 1). This purple ink secretion contains chemicals that has biological activities which includes antibacterial factor, haemagglutins, cytotoxins, and anticancer property. Dolabellanin and dolastatin 10 are compounds isolated from $D$. auricularia that are already on its phase II 
clinical trial as anticancer agent [4]. Moreover, the ink also showed antibacterial activity against pathogens P. aeroginosa and $V$. cholera [5].

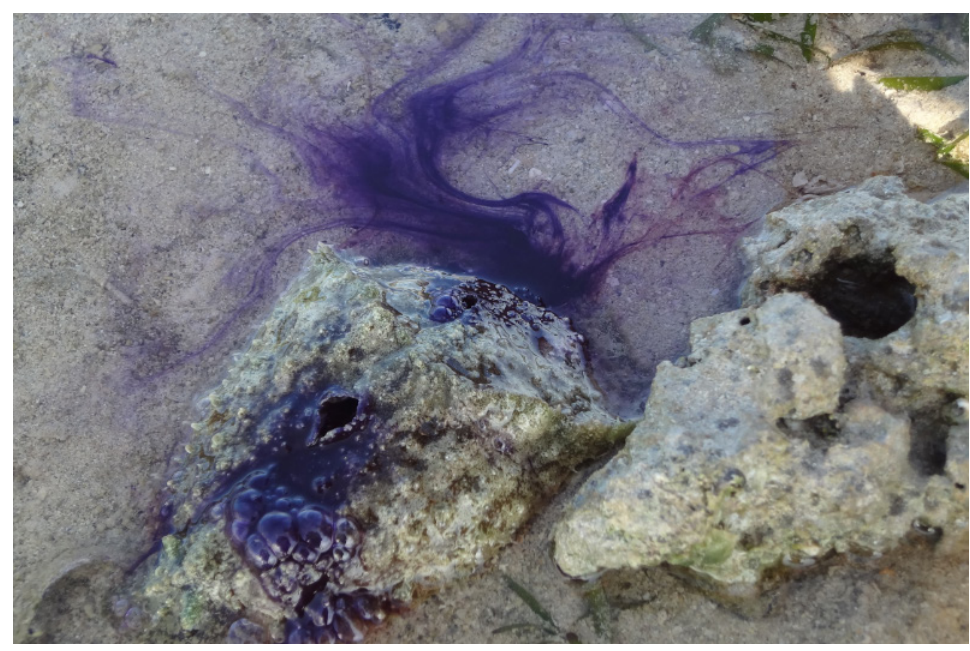

Figure 1 Sea hare releasing its purple ink for defense at the sampling site, Guang-guang, Pujada Bay, Davao Oriental.

The chemical composition of ink from sea hare depends on the algal diet, stage of life and its reproductive cycle, environment, and geographical location [6]. The richness of Pujada Bay's biodiversity is a great factor that will greatly influence the type of metabolites present in the sea hare. In Davao Oriental, studies on mariculture, nutritive value, and commercialization of sea hare and its egg strings were already conducted. However, no current studies on ink has been made on its potential to be a source of compounds which may eventually lead to the development of pharmacological substances. Hence, this study aimed to investigate the chemical composition of ink from sea hare and its antibacterial activity. The information obtained from this study will contribute to the growing literature of Dolabella auricularia as a basis for further chemical studies of sea hare coming from Davao Oriental that will hopefully lead to the discovery of another bioactive and novel compounds.

\section{Materials and methods}

The study site shown in Figure 2 was along the coast of Guang-guang, Pujada Bay, City of Mati, Davao Oriental. Samples were collected between 6 55'25.9" North Latitude $126^{\circ} 15^{\prime} 30.0^{\prime}$ " East Longitude and 6 $6^{\circ} 4^{\prime} 51.4^{\prime \prime}$ North Latitude $126^{\circ} 14^{\prime} 26.8^{\prime \prime}$ East Longitude. The area had a stretch of mangrove reforestation with sandy-muddy substrate. The abundance of sea grass and absence of extreme low tide made it a good fishing ground (Figure 3). 

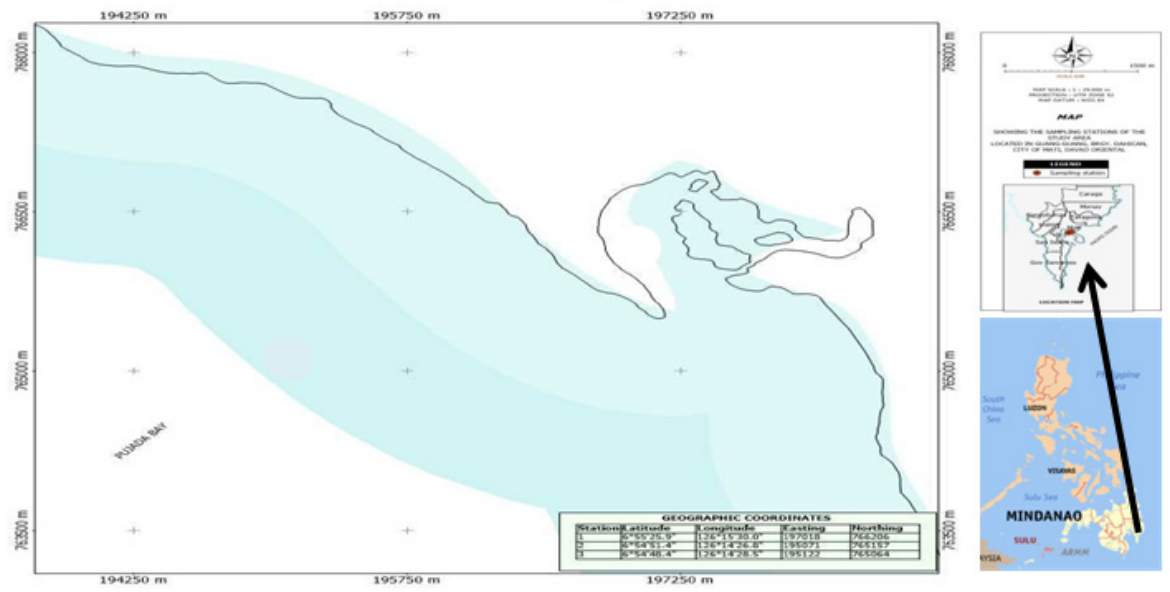

Figure 2 Map of the sampling site in Guang-guang, Pujada Bay, Davao Oriental (CENRO, 2017).

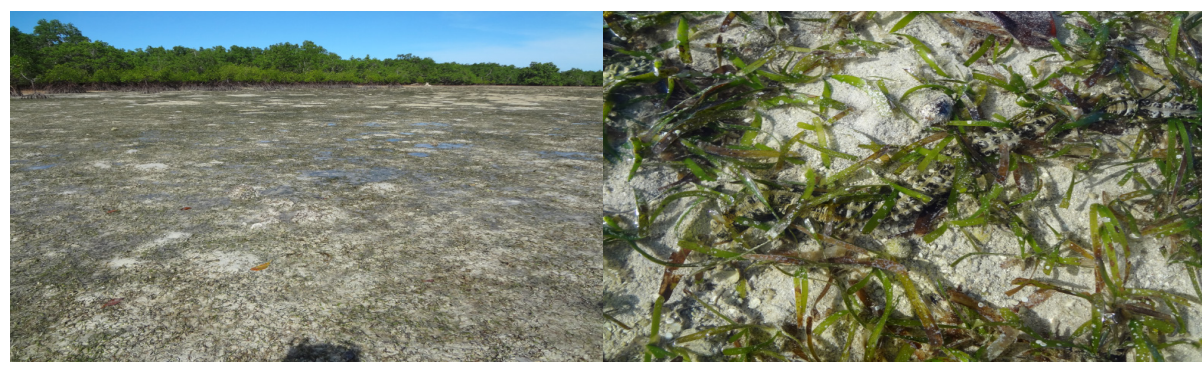

Figure 3 Actual sampling site in Guang-guang, Pujada Bay, Davao Oriental.

\section{Sample collection and preparation}

Sea hare samples were randomly collected and placed in a laboratory pan. A little pressure was exerted on the body of the sea hare to release its ink. About 100 to $200 \mathrm{~mL}$ composite ink sample was collected and transferred into a reagent bottle. Approximately about the same volume of $95 \%$ ethanol was added to the sample and allowed to stand for 24 to $48 \mathrm{~h}$. The mixture was centrifuged, filtered, and subjected to rotary evaporator below $50{ }^{\circ} \mathrm{C}$ to obtain a concentrate. The concentrate was used for both secondary metabolites screening and antibacterial activity [7] while fresh samples were used for the proximate composition and mineral content determination.

\section{Proximate and mineral analyses}

The proximate and mineral composition of ink from sea hare were determined by following the standard official methods of the Association of Official Analytical Chemists (AOAC). Gravimetric method for moisture and ash content was used. Soxhlet for the crude fat, Macro Kjeldahl for the crude protein, UV-VIS for phosphorous and Atomic Absorption Spectrophotometer (AAS) for Na, P, Ca, Mg $\mathrm{Fe}$ and $\mathrm{Zn}$. The concentration of each analysis was reported as the mean of the three replicate fresh ink samples [8]. 


\section{Secondary metabolites screening}

Test for Saponin (Froth test)

One $\mathrm{mL}$ of the extract was placed in a test tube added with one $\mathrm{mL}$ gogo extract and allowed to stand for a few minutes. After then, about ten $\mathrm{mL}$ of distilled water was added to the mixture. The test tube was then stoppered and shaken vigorously for $30 \mathrm{~s}$. A honeycomb froth formation after $10 \mathrm{~min}$ indicated the presence of saponins.

\section{Test for Steroids (Liebermann-Buchard)}

One $\mathrm{mL}$ of the ink extract was added with dichloromethane and stirred. The mixture was allowed to stand for a few minutes before adding 3 drops of acetic anhydride. A change in color of dichloromethane meant a positive result.

\section{Test for alkaloids (Laboratory test tube method)}

A syrupy sample was prepared by evaporating the ink extract. About $5 \mathrm{~mL}$ of $2 \mathrm{M} \mathrm{HCl}$ was added, heated and cooled. The mixture was stirred and filtered after the addition of $0.5 \mathrm{~g} \mathrm{NaCl}$. To one portion of the filtrate, 3 drops of Mayer's Reagent was added while $1 \mathrm{~mL}$ of Dragendorff's reagent was added to another portion. A white and orange precipitate for Mayer's and Dragendorff's reagent respectively meant positive result for alkaloids.

\section{Test for Glycosides (Keller-Kiliani)}

The ink extract was subjected to drying and defatting with petroleum ether. Excess ether was removed by warming the mixture gently. The mixture was divided into two parts. To one part of the mixture, a $3 \mathrm{~mL}$ ferric chloride reagent was added followed by $1 \mathrm{~mL}$ concentrated sulfuric acid. The other part served as control. The mixture was allowed to stand, and color observation was noted.

\section{Test for Flavonoids (Bate-Smith \& Metacalf)}

The ink extract was dried and defatted with petroleum ether. Excess ether was removed. It was diluted with $80 \%$ ethanol, filtered, and divided into two equal portions. One portion was treated with 0.5 $\mathrm{mL}$ concentrated $\mathrm{HCl}$ while the other served as control. A strong red or violet color formation was a positive indication of flavonoids.

\section{Test for Tannins (Ferric chloride test)}

The ink extract was evaporated to dryness and added with hot distilled water and 5 drops of $10 \%$ $\mathrm{NaCl}$ solution. It was filtered and divided into two equal portions. 3 drops of $1 \%$ Ferric chloride reagent was added to one portion while the other serve as control. A change of color (blue-black or brownish green) was an indication of the presence of tannins.

\section{Test for Anthraquinone (Bortntrager's test)}

The ink extract was dried and added with $10 \mathrm{~mL}$ distilled water. It was then filtered. The filtrate was extracted with benzene twice. The combined extract was divided into two fractions. One portion was added with $5 \mathrm{~mL}$ ammonia solution and mixed. The other portion served as control. The red color development in the lower ammoniacal layer indicated the presence of anthraquinones.

\section{Antibacterial activity}

The prepared ink extracts were subjected to antimicrobial screening using an agar well diffusion method. A pathogenic gram positive, Staphylococcus aureus and gram negative Eschericia coli microorganisms were used. Incubation of a loopfull of bacteria in Muller-Hinton Broth was done for $24 \mathrm{~h}$ at $35^{\circ} \mathrm{C}$. A positive growth was indicated by the turbidity of the culture broth. A portion was transferred into a sterile screw capped tube and then agitated on a vortex mixer.

The melted agar was poured into dry sterile petri dishes and solidified. A sterile cotton swab was moistened with the test suspension and then streaked over the entire surface of the agar and allowed to 
http://wjst.wu.ac.th

stand for $5 \mathrm{~min}$. A sterilized cork borer was stabbed into the agar all the way to the bottom of the dish to create a well and filled with the extract. The dish was incubated $24 \mathrm{~h}$ at $35^{\circ} \mathrm{C}$. The antibacterial activity of the extract was determined by measuring the zone of inhibition against the values produced by the standard drugs ampicillin and penicillin.

\section{Results and discussion}

On the average, collected sea hare samples measured 5 inches and weighed 300 grams. Its color was mottled green that camouflage with the sandy muddy substrate as one of their defense mechanisms aside from their purple ink chemical defense.

\section{Proximate composition}

The chemical composition of many marine organisms is said to be affected and influenced directly by diet, stage of life and its reproductive cycle [6]. The result for proximate composition as wet basis was summarized in Table 1. It showed that ink was composed mostly of water (90.4\%), followed by crude fat $(5.32 \%)$, the ash content that speaks about the mineral content of the ink for both macro and micro nutrients $(2.04 \%)$ and lastly crude protein $(0.75 \%)$.

Accordingly, among marine species, the concentrations of fat vary more than protein and carbohydrate. This is due to their responses to environmental conditions, physiological traits and feeding. The high crude fat content $(5.32 \%)$ compared to protein and mineral content of the ink can be an indication of greater ability of sea hare to store lipid [6]. The concentration of protein maybe low; however, this should not be underestimated since it is a source of amino acids such as phenylalanine and tyrosine that can be converted through metabolic process into phenolic compounds [9].

Table 1 Proximate analyses of ink from Dolabella auricularia.

\begin{tabular}{lc}
\hline \multicolumn{1}{c}{ Parameter } & Composition (\%) \\
\hline Moisture content & $90.4 \pm 0.32$ \\
Ash content & $2.044 \pm 0.55$ \\
Crude fat content & $5.324 \pm 6.62$ \\
Crude Protein content & $0.75 \pm 0.33$ \\
\hline
\end{tabular}

Each value was the average of three measurements \pm SD.

\section{Mineral composition}

The mineral content of ink from sea hare as shown in Table 2 revealed that ink can be a good source of minerals for both macro and micronutrients. The samples contained a large quantity of sodium $(0.662 \%)$ which was followed by phosphorous with a mean of $0.25 \%$. Magnesium and potassium were also present in moderate quantity; the average amount of $664 \mu \mathrm{g} / \mathrm{g}$ of magnesium and $578.6 \mu \mathrm{g} / \mathrm{g}$ of potassium while calcium concentration was only $310.8 \mu \mathrm{g} / \mathrm{g}$. On the other hand, the concentration of micronutrients iron and zinc were $2.146 \mu \mathrm{g} / \mathrm{g}$ and $1.898 \mu \mathrm{g} / \mathrm{g}$ respectively.

The phosphorous concentration in this study fell within the range for most marine invertebrates (0.24 to $1.16 \%)$ [6]. Accordingly, slow moving animals like sea cucumber usually have low $\mathrm{P}$ concentrations with abundant inorganic substances in their system. The phosphorous' requirement for a slow-moving organisms is lower than fast moving organisms since it needs more ATP to provide energy for their locomotion [10].

The result of this study is important in consideration of the minerals ( $\mathrm{Ca}, \mathrm{K}, \mathrm{P}, \mathrm{Na}, \mathrm{Mg}, \mathrm{Fe}$ and $\mathrm{Zn}$ ) usefulness in the body. Calcium is needed for both therapeutic and prophylactic effect. Zinc is important for sexual development, reproduction, and normal growth [11]. While most of the studies conducted on marine organisms focuses on the tissues, less literature is found for the nutrient analysis of the ink. This 
http://wjst.wu.ac.th

result may be the first work on nutrient content in ink of sea hare from Davao Oriental, Philippines and can be significant for its use in pharmacological studies.

Table 2 Mineral composition of ink from Dolabella auricularia.

\begin{tabular}{cc}
\hline \multicolumn{1}{c}{ Mineral } & Concentration \\
\hline A. Macronutrients & \\
\hline Phosphorous, $\%$ & $0.25 \pm 0.00$ \\
Potassium, $\mu \mathrm{g} / \mathrm{g}$ & $578.6 \pm 169.43$ \\
Sodium, $\%$ & $0.662 \pm 0.17$ \\
Calcium, $\mu \mathrm{g} / \mathrm{g}$ & $310.8 \pm 58.61$ \\
Magnesium, $\mu \mathrm{g} / \mathrm{g}$ & $664 \pm 205.19$ \\
\hline B. Micronutrients & \\
\hline Iron, $\mu \mathrm{g} / \mathrm{g}$ & $2.146 \pm 0.54$ \\
Zinc, $\mu \mathrm{g} / \mathrm{g}$ & $1.898 \pm 0.20$ \\
\hline
\end{tabular}

Each value was the average of three measurements $\pm \mathrm{SD}$.

\section{Secondary metabolites screening}

The results of secondary metabolites screening revealed that sea hare's ink contained saponins, steroids and flavonoids. The honeycomb formation of Froth test, blue color formation of LibermannBuchard test and development of red color solution with Bate-Smith and Metacalf test indicated the presence saponins, steroids and flavonoids respectively. Dragendorff's and Mayer's reagent, KellerKiliani, ferric chloride and Bortntrager qualitative test showed negative results for alkaloids, glycosides, tannins and anthraquinones respectively (Table 3).

Table 3 Secondary metabolites screening of Ink extract from sea hare.

\begin{tabular}{lllc}
\hline \multicolumn{1}{c}{ Secondary metabolites } & \multicolumn{1}{c}{ Test } & \multicolumn{1}{c}{ Observation } & Remarks \\
\hline Saponin & Froth Test & Honey comb formation & + \\
Steroids & Liebermann-Buchard & Blue color formation & + \\
alkaloids & Laboratory Test Tube Method & No color change & - \\
Glycosides & Keller-Kiliani & No color change & - \\
Flavonoids & Bate-Smith \& Metacalf & Red color formation & + \\
Tannins & Ferric Chloride Test & No color change & - \\
Anthraquinones & Bortntrager's Test & No color change & - \\
\hline
\end{tabular}

Legend: (-) absence, $(+)$ presence

Each trial was done in three replicates.

Several reviews showed that flavonoids possess wide spectrum of biological activities in cardiovascular system, which include antioxidant, antithrombotic, antiapoptic, anti-ischemic, antiarrhythmic, and anti-hypertensive activities [12,13]. Saponins have considerable commercial value and were processed as drugs and medicines, foaming agents, sweeteners, taste modifiers and cosmetics $[14,15]$. Furthermore, saponins are neutraceutically important sine its derivative can be easily absorbed by gut secretions and its glycosidic linkage is easily cleaved of [16]. While steroids have a wide range of functions from hormonal regulation to digestion to poison which depends on the substituent attached on the large ring system [17]. 
Although there were only seven secondary metabolites tested qualitatively which limits the results of this study, more could have been determined should the number of secondary metabolites tested was increased. Accordingly, the types of secondary metabolites of sea hares are very much dependent on their algal diet and environment as well as its geographical location. Hence, sea hare can accumulate different secondary metabolites. For example, secondary metabolites terpene palisadin, halogenated furanone 3 were isolated from Aplysia parvula and Aplysia dactylomela [18]. While compounds aplysioviolin, prepacifinol epoxide and its derivative johnstonol and (-)-7-dehydrocholesterol were isolated from the $D$. auricularia [19]. The result of this study clearly showed that ink from sea hare is a good source of secondary metabolites. Also, this result will now be a basis for further studies to quantify the amount of such metabolites present.

\section{Anti-microbial activity}

The ink extract showed a weak antimicrobial activity compared to the standard drugs. The $6.0 \mathrm{~mm}$ zone of inhibition against $E$. coli and $S$. aureus was comparatively weak compared to the standard ampicillin and penicillin which exhibited zone of inhibition at 18 and $26 \mathrm{~mm}$ in diameter respectively as shown in Table 4. Accordingly, sea hares may have different microbial components with varying strength and concentration that greatly affects their antimicrobial threshold [18]. Hence, the low antimicrobial activity of D.auricularia from Davao Oriental, Philippines may be attributed to the type of antimicrobial compound present and its concentration. However, the presence of saponins, steroids and flavonoids may also be responsible or had contributed to its seemingly weak antimicrobial activity since these compounds generally have antibacterial factor [20,21].

Table 4 Antimicrobial activity of ink from Dolabella auricularia.

\begin{tabular}{ccc}
\hline Trial & $\begin{array}{c}\text { Gram positive } \\
\text { Staphylococcus aureus }\end{array}$ & $\begin{array}{c}\text { Gram negative } \\
\text { Eschericia coli }\end{array}$ \\
\hline 1 & + & + \\
2 & + & + \\
3 & + & + \\
Ampicillin & +++ & Not tested \\
Penicillin & Not tested & ++++ \\
\hline
\end{tabular}

Note: (-) indicate no activity, $(+)$ weak activity with inhibition 1-6 mm, (++) slight activity with inhibition 7 - $12 \mathrm{~mm}$, $(+++)$ moderate activity with inhibition $13-18 \mathrm{~mm}$ and $(++++)$ high activity with inhibition $>19 \mathrm{~mm}$.

\section{Conclusions}

This study had shown the proximate composition, mineral content, secondary metabolites screening and antimicrobial activity of ink from sea hare of Pujada Bay, City of Mati, Davao Oriental. Preliminary results of this study showed that ink of sea hare from Davao Oriental was a good source of primary and secondary metabolites and it had antimicrobial factor. These findings add knowledge to the potential medicinal value of sea hare and can be a basis for further chemical studies that will hopefully lead to the discovery of compounds with pharmacological importance.

\section{Acknowledgements}

The author is grateful to Davao Oriental State University through the Research, Development and Extension division for funding this study. 
http://wjst.wu.ac.th

\section{References}

[1] TL Simmons, E Andrianasolo, K McPhail, P Flatt and WH Gerwick. Marine natural products as anticancer drugs. Mol. Canc. Therapeut. 2005; 4, 333-42.

[2] CP Hickman Jr., LS Roberts, SL Keen, A Larson, HI Anson and DJ Eisenhour. Integrated principles of zoology. McGraw-Hill, New York, 2008, p. 331-60.

[3] SC Pennings and VJ Paul. Sequestration and dietary secondary metabolites by three species of sea hares: Location, specificity and dynamics. Mar. Biol. 1993; 117, 535-46.

[4] Natural products from the Sea: Ethnopharmacology, nutrition and conservation, Available at: http://findarticles.com/p/articles/mi_mOIS/is_2001_Feb/ai70777319, accessed March 2016.

[5] P Abirami, M Arumugam, TT Ajithkumar and T Balasobramanian. Isolation and characterization of $37 \mathrm{kDa}$ heparinase from the purple fluid of D. auricularia. Indian J. Mar. Sci. 2010; 40, 112-6.

[6] G Diniz, E Barbarino, J Neto, S Pacheco and S Lourenço. Proximate composition of marine invertebrates from tropical coastal waters, with emphasis on the relationship between nitrogen and protein contents. Lat. Am. J. Aquat. Res. 2014; 42, 332-52.

[7] BQ Guevara. A Guidebook to plant screening: Phytochemical and biological. Research Center for the Natural Sciences, University of Santo Tomas, Philippines, 2004, p. 26-50.

[8] K Helrich. Official methods of analysis of the association of official analytical chemists. Vol I. Association of Official Analytical Chemists, Virginia, USA, 1990, p. 40-88.

[9] D Pereira, P Valentao, J Pereira and P Andrade. Phenolics: From chemistry to biology. Molecules 2009; 14, 2202-11.

[10] M Ogawa and EL Maia. Manual de Pesca: Ciência e Tecnologia do Pescado. Vol I. São Paulo, Varela, Brazil, 1999, p. 430.

[11] PB Ayoola and OOE Onawumi. Proximate analysis and phytochemical investigation of Plukenetia conophorum stem bark. Eur. J. Biomed. Pharmaceut. Sci. 2015; 2, 44-7.

[12] T Shohaib, M Shafique, N Dhanya, $\mathrm{C}$ Madhu and $\mathrm{C}$ Divakar. Importance of flavonoids in therapeutics. Hygeia. J. Drugs Med. 2011; 3, 1-18.

[13] SMM Mohy El-Din and AMD El-Ahwany. Bioactivity and phytochemical constituents of marine red seaweeds (Jania rubens, Carollina mediterranea and Pterocladia capillacea). J. Taibah Univ. Sci. 2016; 10, 471-84.

[14] VK Hostettmann and A Marston. Saponins. Pharmazie 1995; 25, 219-20.

[15] Y Thambidurai, D Sudarsanam, SKM Habeeb and JK Kizhakudan. Screening of bioactive compounds from marine sponges collected from Kovalam, Chennai. Asian J. Pharm. Clin Res. 2017; 10, 231-6.

[16] VR Netala, SB Ghosh, P Bobbu, D Anitha and V Tartte. Triterpenoid saponins: A review on biosynthesis, applications and mechanism of their action. Int. J. Pharm. Pharm. Sci. 2015; 7, 24-8.

[17] PS Bailey and C Bailey. Organic chemistry: A brief survey of concepts and application. PrenticeHall, Inc. New Jersey, 2000, p. 450-4.

[18] CN Rogers, DNTS Charlton and PD Steinberg. Dynamics of algal secondary metabolites in two species of sea hare. J. Chem. Ecol. 2000; 26, 721-44.

[19] PM Johnson, CE Kicklighter, MK Schmidt, H Yang, D Elkin, WC Michel, PC Tai and CD Derby. Packaging of chemicals in the defensive secretory glands of the seahare Aplysia californica. J. Exp. Biol. 2006; 209, 78-88.

[20] E Khatiwora, VB Adsul, MM Kulkarni, NR Deshpande and RV Kashalkar. Spectroscopic determination of total phenol and flavonoid contents of Ipomoea carnea. Int. J. Chemtech. Res. 2010; 2, 1698-701.

[21] MRS Ardekani, M Hajimahmoodi, MR Oveisi, N Sadeghi, J Behrooz, AM Ranjbar and T Moridi. Comparative antioxidant activity and total flavonoid content of persian pomegranate (Punica granatum L.) cultivars. Iran J. Pharm. Res. 2011; 10, 519-24. 